\title{
Overlapping Fiscal Domains and Effectiveness of Environmental Policy in India
}

\author{
Subrata Mandal \\ and \\ M. Govinda Rao
}




\title{
Overlapping Fiscal Domains and Effectiveness of Environmental Policy in India
}

\author{
Subrata Mandal* \\ and \\ M. Govinda Rao**
}

\begin{abstract}
The paper analyses the assignment systems and implementation aspects of environmental regulation in regard to water, air, and forests. The assignment of environmental functions and its overlapping is analysed in terms of not only the different levels of government, but also between the executive and judiciary. Specifically, the paper examines judicial intervention in environmental protection in India and argues that judicial activism although can be construed as a part of "checks and balances" in a federal system, it cannot be a substitute to the failure of executive in undertaking the task of environmental protection. The paper also analyses the implementation aspects of environmental policy, particularly the effectiveness of policies and institutions relating to environmental governance.
\end{abstract}

Despite a reasonably clear assignment system, the implementation of environmental functions has not been satisfactory.

* Senior Economist, National Institute of Public Finance and Policy, New Delhi. E-mail: subrata@nipfp.org.in.

** Director, National Institute of Public Finance and Policy, New Delhi.

E-mail: mgr@nipfp.org.in. 
In most cases, an important factor impeding effective implementation is seen in the structure of incentives to bureaucracy and policy makers and influence of polluters on them. Besides, the environmental regulators do not have access to modern technology and inadequate resources to measure and regulate pollution levels.

The paper highlights overlapping roles of executive and judiciary in implementing environmental regulation. In other words, failure of the executive to regulate and monitor pollution levels as well as forest cover has led to the Supreme Court intervention. Interpreting that access to clean water and air as a fundamental right, the courts have pronounced several judgements on the implementation of environmental regulation virtually taking over the role of executive. This has helped to resolve the issues in the short term and in some cases has led to the improvement in environmental quality. However, the solution is ad hoc as the courts cannot undertake the task of implementation nor do they have the technical knowledge to deal with complex problems of environmental regulation. Besides, technology is not static and mandating a technical solution through a judgement such as the use of a particular technology or particular fuel for running of commercial vehicles can create serious problems in the long term. The solution lies in reforming the incentive structure and institutions of governance to make the executive much more sensitive and accountable to environmental issues. 


\section{Overlapping Fiscal Domains and Effectiveness of Environmental Policy in India}

\section{Introduction}

An important pre-condition for satisfactory provision of public services is the assignment of fiscal domains to, and their implementation by different levels of government. A clear and inextinguishable assignment system confers ownership rights and this provides incentives for making the necessary investments, ensures efficiency and accountability in the provision of public services.

Fiscal assignments however well construed and designed, do involve overlapping, as the geographical boundaries may not coincide with the benefits of various public services. In part, overlapping fiscal system is the result of vertical and horizontal competition and the competition in turn can accentuate overlapping (Breton, 1995). Satisfactory resolution of this is an important challenge in all multilevel fiscal systems. The issue is particularly relevant in the context of environmental protection because, even the issues with local environmental jurisdictions and applications have global implications.

This paper analyses the assignment of environmental functions in Indian federalism. More specifically, it examines the assignment system and implementation aspects pertaining to three major components of environment, namely, water, air, and forests. The assignment of environmental functions and its overlapping is analysed in terms of not only the different levels of government, but also between the executive and judiciary. Specifically, the paper examines judicial intervention in environmental protection in India and argues that activism is not a solution or a substitute to the failure of the executive in undertaking the task of environmental protection. 


\section{The Assignment System}

An important dimension of federalism is the assignment of the power to own and manage natural resources. Both, from the viewpoint of principles and contemporary practices, it is difficult to discern an ideal assignment system. The endowment of natural resources across regions is uneven and distributional considerations dictate against the assignment of natural resource management to subnational governments. Further, exploitation of important natural resources also involves significant inter-regional externalities and their assignment to the subnational governments could lead to inefficient resource allocation (Musgrave, 1983). It could also cause significant differences in the tax effort as the state with significant natural resources may decide to use origin based natural resource revenues rather than destination based taxes ${ }^{1}$. For this reason, Indian Constitution assigns the right to exploit major minerals to the centre and minor minerals to the states. (Rao and Singh, 2004. ch. 10).

The Indian Constitution under Article 246, empowers the Union ${ }^{2}$ Parliament and the state legislatures to enact and implement laws relating to activities under their domain. The seventh schedule to the constitution assigns the responsibilities of the two levels of government under the "union", "state" and "concurrent" lists. The central and state governments have exclusive authority over the union and state lists respectively and both the levels have jurisdiction over the activities in the concurrent list with the former having overriding powers. The residual power to legislate on the subjects not covered in the three lists is delegated to the centre by Article 248. Article 249 empowers the centre to legislate on any subject in the state list in the "national interest", it can also enact laws on state subject if two or more state legislatures consent to such legislation (Article 252). Article 253 empowers the centre to make laws necessary to implement treaties to which India is a signatory and decisions of conferences of which India is a participant. Under special or extreme situations, the centre can even dismiss a state government and take over its governance (Article 356). These features of the constitution show centripetal bias in the Indian constitution. Such a backdrop of central dominance in policy making in general has contributed to a dominant role of central government in matters related to environmental legislation too. 
The functions related to regulation and development of interstate rivers and river valleys, fishing and fisheries beyond territorial water, shipping and navigation, of inland waterways, maritime shipping and navigation and entering agreements with foreign countries have been assigned to the central government. The state governments are empowered to legislate on subjects related to water supplies, irrigation and canals, drainage and embankment, water storage and waterpower, subject to the provisions of Entry 56 of union list, and fisheries. Emissions from factories and shipping and navigation on inland waterways as regards mechanically propelled vessels figure in the concurrent list. The assignment system in regard to air is much more ambiguous. Air pollution does not directly figure in any of the three lists and have to be traced only by implications. Regulation of mines and mineral development figures in the central list, the central government would therefore be responsible for air pollution related to mines. Similarly the central government is responsible for any pollution related to public sector industries controlled by the central government. Public health and sanitation figures in the state list, this empowers state governments to legislate on health aspect related to pollution. The assignment of legislative power in regard to the protection of forests and wildlife was in the state list till 1976, but was brought to the concurrent list by an (fortysecond) amendment of the constitution.

The third tier of government was introduced in the Indian Constitution by the $73^{\text {rd }}$ and $74^{\text {th }}$ Amendment in 1992. The third tier is the local government at rural and urban areas. Rural local governments are called Panchayats and they have been constituted at district, block, and village levels. The urban local governments are the municipal corporations, municipalities and for smaller towns, Nagarapalikas. These already existed in some states, and after the amendments, these local bodies were conferred the constitutional status.

The eleventh and twelfth schedules to the constitution list the subjects to be devolved to the rural and urban local governments respectively, but these are carried out concurrently with the state governments. The environmental functions listed for the rural local governments include land improvement, land consolidation and soil conservation, minor irrigation, water management and watershed development, fisheries, social forestry and farm forestry, minor forest products, drinking water, fuel and fodder, non-conventional energy sources and maintenance of community assets. For urban local bodies, 
the list includes subjects like water supply for domestic, industrial, and commercial purposes; public health, sanitation, conservancy and solid waste management; and urban forestry, protection of the environment and promotion of ecological aspects, provision of urban amenities and facilities such as parks, gardens, and playgrounds are listed.

\section{Environmental Regulation in India}

The UN conference on Human Environment held at Stockholm in 1972 exerted major influence and has been a driving force in environmental legislation and policy making in India. The Government of India initiated a number of steps to implement the decisions taken at the conference by means of amendments to the constitution, new legislation relating to environmental protection and creation of institutions for implementing legislation. In 1976, environmental protection and improvement were explicitly incorporated into the constitution by the Constitution (Forty Second Amendment) Act. Specific provisions were inserted into the Directive Principles of the State Policy and Fundamental Duties. Article 48A which was added to the directive principles states, "...the State shall endeavor to protect and improve the environment and to safeguard the forests and wild life of the country". Article $51 \mathrm{~A}(\mathrm{~g})$ in a new chapter entitled, "Fundamental Duties", imposes a similar responsibility on every citizen "to protect and improve natural environment including forests, rivers, lakes and wild life and to have compassion for living creatures." Together these two provisions lay the foundation for jurisprudence of environmental protection. The amendment also expanded the list of concurrent powers by moving "Forests" and "Protection of Wild Animals and Birds" from the state list to the concurrent list.

In 1972, Parliament enacted the Wild Life Protection Act prior to the Stockholm conference. The act provides for state wildlife advisory boards, regulations for hunting wild animals and birds, establishment of national parks and sanctuaries, regulations for trade in wild animals, and judicially imposed penalties for violating the act. The act is administered by wildlife wardens and their staff. In 1972, when the act was introduced 
by the central government, wildlife was a state subject, in fact, 11 states introduced resolutions allowing the central government to legislate under Article 252(I) of the constitution. The move for centralisation of provisions for wild life protection thus came from the states themselves. An amendment to the act in 1982 allowed for capture and transportation of wild animals for scientific management. Subsequently, another amendment in 1991 recognised the needs of tribal and forest dwellers.

The core of early environmental legislation relates to forests. The state played an important role in forest management since the establishment of forest department in 1864 with the help from Germany, the leading European nation in forest management at the time. The colonial government immediately introduced the Indian Forest Act in 1865 and asserted propriety right of the state over forests. The act of 1865 was made further stringent in 1878 to make a comprehensive legislation, which inter alia, transferred the ownership and management of forest from the village level to a centralised state. The act disregarded centuries of customary use by rural population and alienated peasant and tribal communities. The 1878 Act was later amended to become the Indian Forest Act, 1927, which is still in force.

The significant central government intervention in the postindependence era was seen in the enactment of The Forest (Conservation) Act in 1980 to prevent the alarming rate of deforestation and the consequent ecological imbalance and environmental degradation by assigning a supervisory role for the central government. The act was amended in 1988, it provides for the approval of the central government if a state decides to de-reserve a reserved forest, use forest land for non-farm purposes, assign forest land to a private corporation and clears forest land for the purpose of reforestation.

The Water (Prevention and Control of Pollution) Act of 1974 was the first important environmental legislation in India. The constitution does not unambiguously place water either as a state subject or as a union subject. The history and the preamble of the Water Act suggest that only state governments can enact water pollution legislation. During the decade long deliberations that preceded the introduction of the legislation in the Parliament, twelve states passed enabling resolutions urging the centre to legislate on the subject since it involved inter-state externalities. 
This act paved the way for creation of Central Pollution Control Boards (CPCB) and State Pollution Control Boards (SPCB). It confers regulatory authority in state boards and empowers them to establish and enforce effluent standards for factories discharging wastewater into the water bodies. The central board performs these functions for union territories and coordinates activities among the states. These boards play advisory role for the respective governments on matters related to location of industries and any matter related to control of pollution. The CPCB is vested with the responsibility of collecting, compiling and publishing data on water pollution and disseminate information related to treatment and disposal of sewage. It also has the mandate to carry out and sponsor investigation and research on pollution abatement. The boards were empowered to enforce the act through criminal prosecution and injunctions to restrain polluters. Later, the act was amended in 1988 to bolster the enforcement machinery by giving them powers to close defaulting industrial plants or withdraw the supply of power and water by an administrative order.

The Air (Prevention and Control of Pollution) Act of 1981 was enacted under Article 253 to implement the decision taken at the United Nations Conference on Human Environment held at Stockholm in 1972. The act expanded the authority of the CPCB and SPCBs established under the Water Act to include problems of air pollution also. The states not having a water pollution board were required to set up an air pollution board. The boards were required to prescribe emission standards for industry and automobiles after taking into account the ambient air quality standards. They were also required to issue permit to industries operating in designated air pollution control areas. To strengthen its enforcement, the act was amended in 1987 to introduce stiffer penalties and empowering the boards to penalise the defaulting plants to close operation on exceeding the emission standards, if necessary.

The Environment Protection Act of 1986 was enacted in the wake of the Bhopal gas tragedy. It is an umbrella legislation designed to provide a framework for the central government to coordinate the activities of various central and state authorities created under the Water Act and Air Act. It delegates wide powers to the executive to enable bureaucrats to frame necessary rules and regulations. The provision of this act and subordinate rules can override any other law. A broad rule making power was conferred on the central government; it was authorised to take all measures that it deemed necessary for the purpose 
of protecting the environment. Some of these measures included setting new national standards for improving the quality of environment, standards for controlling emissions and effluent discharges, to locate industrial sites, and to establish safeguards for preventing accidents.

The central government enacted the Public Liability Insurance Act in 1991 to provide immediate relief to victims of accidents involved in handling hazardous substances. The act requires the owner to compensate the victims irrespective of any neglect or default. The principal authority to administer the act is the District Collector. The act obligates every owner to take an insurance policy covering potential liability from accidents. Every owner was also required to contribute in toto an Environmental Relief Fund established by the central government. The act was amended in 1992 to introduce provisions relating to the fund and to place a cap of Rs. 450 million (about 10 million US\$). The National Environmental Tribunal Act of 1995 builds on the Public Liability Insurance Act of 1991 for providing relief to victims of accidents involving hazardous substances. The act empowers the central government to establish a national tribunal at New Delhi with powers to entertain applications for compensation, enquire into such claims and make an award determining the compensation to be paid. The act imposes a bar on all civil courts from entertaining any claim that may be dealt with by the tribunal. An award may be challenged in the Supreme Court or impugned in a petition to the High Court.

The National Environment Appellate Authority Act of 1997 requires the central government to constitute a national environment appellate authority for hearing appeals against orders granting environmental clearance in areas where restrictions are imposed on setting up any industry or carrying on any operation or process. ${ }^{3}$

\section{Centralisation and Decentralisation in Indian Environmental Politics}

Political factors have impacted on environmental issues to influence laws, regulations, acts, court orders, directives, conventions and formulation and implementation of policies and programmes. In 
particular, swings between centralisation and decentralisation of political power have impacted on the control and use of natural resource like water, air, forests, and species of animals used in economic activities like agriculture and industry. The attempt here is to trace the forces of centralisation and decentralisation at various levels of governance: national, provincial, regional, and local. Table 1 tries to capture these aspects in a structured manner. It tries to look at the aspect of industrial pollution, ecosystem protection, agriculture, forests and implementation, and enforcement of related action plans at various levels of governance.

In regard to industrial pollution, the impact of air pollution is global and hence, we see the formation of global protocol limiting CFCs and greenhouse gases. The protocol has been implemented in India by the national government through the Air Act. The regulation of local air pollution due to vehicular use and industrial emission has come mainly from the intervention of NGOs and Public Interest Litigations (PILs) ${ }^{4}$ in the Supreme Court. With respect to water pollution the implications are inter-jurisdictional since it has spillover effects. The states in India voluntarily asked for national law in such case. At the local level too there have been PILs against pollution of local water bodies. 
Table 1: Centralisation and Decentralisation in Indian Environmental Politics

\begin{tabular}{|c|c|c|c|c|c|c|}
\hline Field/level & $\begin{array}{l}\text { Industry } \\
\text { Pollution }\end{array}$ & $\begin{array}{l}\text { Ecosystem } \\
\text { Protection }\end{array}$ & Agriculture & Forests & Water & $\begin{array}{l}\text { Implementation } \\
\text { and Enforcement }\end{array}$ \\
\hline International & $\begin{array}{l}\text { Montreal } \\
\text { Protocol (CFC } \\
\text { regulation) }\end{array}$ & CITES ** & & $\begin{array}{l}\text { Convention on } \\
\text { Biological } \\
\text { Diversity }\end{array}$ & $\begin{array}{l}\text { Indus Water } \\
\text { Treaty } \\
\text { Joint River } \\
\text { Commission } \\
\text { (Bangladesh) }\end{array}$ & \\
\hline National & $\begin{array}{l}\text { Water, Air, } \\
\text { Environment } \\
\text { Protection, } \\
\text { Public Liability } \\
\text { Insurance } \\
\text { Acts }\end{array}$ & $\begin{array}{l}\text { Wild Life } \\
\text { Protection Act } \\
(1972) \\
\text { National Parks } \\
\text { and } \\
\text { Sanctuaries }\end{array}$ & $\begin{array}{l}\text { Command Area } \\
\text { Development } \\
\text { River Valley } \\
\text { Projects }\end{array}$ & $\begin{array}{l}\text { The Forest } \\
\text { Conservation Act, } \\
1980\end{array}$ & $\begin{array}{l}\text { The water } \\
\text { (Prevention } \\
\text { and Control } \\
\text { of Pollution) } \\
\text { Act (1974) } \\
\text { Water } \\
\text { Tribunals }\end{array}$ & $\begin{array}{l}\text { Supreme Court } \\
\text { Directives on air } \\
\text { and water pollution } \\
\text { Environmental } \\
\text { Impact Assessment }\end{array}$ \\
\hline $\begin{array}{l}\text { Provincial/ } \\
\text { State }\end{array}$ & $\begin{array}{l}\text { Legislation } \\
\text { for Central } \\
\text { Law }\end{array}$ & & $\prod_{\square}^{\text {Dams }}$ & Deforestation & $\begin{array}{l}\text { Water } \\
\text { Disputes, } \\
\text { Groundwater } \\
\text { regulations }\end{array}$ & $\begin{array}{l}\text { Supreme Court } \\
\text { Directives on ban } \\
\text { on tree felling }\end{array}$ \\
\hline $\begin{array}{l}\text { Regional/ } \\
\text { Districts }\end{array}$ & & & Tanks & $\begin{array}{l}\text { Watershed } \\
\text { Development }\end{array}$ & $\begin{array}{l}\text { Watershed } \\
\text { Development }\end{array}$ & \\
\hline Local & $\begin{array}{l}\text { NGO } \\
\text { Action }\end{array}$ & & $\begin{array}{l}\text { Participatory } \\
\text { Irrigation } \\
\text { Management } \\
\text { Wells }\end{array}$ & $\begin{array}{l}\text { Joint Forest } \\
\text { Management }\end{array}$ & $\begin{array}{l}\text { Water Users' } \\
\text { Association }\end{array}$ & $\begin{array}{l}\text { Public Interest } \\
\text { Litigation }\end{array}$ \\
\hline
\end{tabular}

${ }^{* *}$ Convention on International Trade in Endangered Species of Wild Fauna and Flora (CITES)

Centralisation Decentralisation<smiles>C1CCCC1</smiles>

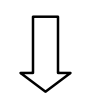


The case of agriculture and the issue of water use seem vexed and potentially volatile. There are big irrigation and river valley projects and dams and command area development projects mainly controlled by the central government and in some cases, state governments. The sharing of river water has been a volatile issue involving property rights, bargaining power and with inter-jurisdictional implications. Despite legislating central acts and establishment of tribunals, solution to the problem has been elusive and many states in India are engaged in bitter fights. In more recent years, however, the attempt has been to encourage decentralised systems and the political power has shifted to the water users' associations and watershed development projects with a distinct local level component in planning and participation. This has resulted in a paradigm shift to management by pressure groups at local levels.

Deforestation is a massive problem in India where the resource is controlled and managed by the state governments. Nexus between contractors, politicians, and bureaucrats has become rampant in exploiting the resource, the trend is combined with population pressure, which needs forest products but is alienated from the upkeep of the forest. The recent initiative in decentralised control with the introduction of joint forest management between the people and the government and the formation of village forest committees has met with some degree of success, however.

With regard to implementation and enforcement of regulations, the Supreme Court has been extremely active forcing governments at the central and state level to implement some of the regulations formed by the governments themselves by responding to PILs. The pollution control boards mandated environmental impact assessment for certain categories of industries to strengthen the regulations to control industrial pollution. The role of specialised agencies set up to regulate environment as also the role of the judiciary in monitoring the implementation of laws are discussed in greater detail below. 


\section{Environmental Regulation in India: Forests}

\section{Evolution of Policy}

The colonial administration declared the proprietary rights of the state over forests, and it was subsequently determined to what extent these were limited by legally existing rights of private persons or communities. After independence in 1947, the Government of India made no substantive changes to this administrative structure. The state retained exclusive control over the management and protection of forest resources. The principles, which were to guide the forest policy of independent India, were enunciated in the National Forest Policy of 1952. The policy reiterated the principles of colonial forestry, as enshrined in the earlier forest policy resolution of 1894 , and reinforced the exclusive rights of the state with regard to the management and control of forest resources. A goal was adopted for bringing 60 percent of the area in hilly tracts and 20 percent of the area in plains (one-third of the country's total geographical area) under forest cover for ecological reasons.

\section{Assignment of Powers}

The Indian Forest Act of 1927 provides the core of regulations and institutions governing forest management and preservation. In essence, control of forests has resided with state governments. The state governments have appointed forest officers, a cadre of state bureaucracy, as on-the-ground implementers of forest management. A 'Secretary' who belongs to the administrative cadre heads the state forest administration. $\mathrm{He}$ is assisted by the conservators of forests belonging to the 'Indian Forest Service' who are technically more competent to manage forests as compared to the officers belonging to the administrative cadre. At the district level the District Forest Officer (DFO) is the administrative head, below him there are Range Officers (RO) who administer the forests in different ranges of districts. These officers have often functioned relatively autonomously, and their ability to control the use of the natural resource without adequate monitoring has allowed them to engage in rent seeking (Wade, 1988). Thus, collusion between state forest officers, contractors and logging companies is acknowledged to be widespread, to the detriment of forest preservation. 
The Forest (Conservation) Act was passed in 1980, which gave the central government the power to control. State governments' decision to divert forest area for non-forest uses. The administrative centralisation required a recasting of the responsibilities and duties of some of the departments of the central government that were responsible for forest planning. The Director General of Forests (DGF) is the administrative head of the forest and wildlife related issues of the Union Ministry of Environment and Forest (MoEF).

There are three divisions supervised by the DGF, two of these relate to forest conservation and the third one is for wild life protection. One division is headed by Additional Director General of Forest (of forest service cadre) and the division coordinates its conservation programme through seven regional offices, each headed by a Chief Conservator of Forests. Other functions of the division are to formulate policies, conduct surveys, conduct training programmes and undertake research and documentation. The Indian Council for Forest Research and Education (ICFRE) has been set up to facilitate research and documentation and use of scientific knowledge for preservation of forest and wild life. The council has set up several institutes to conduct its research activities. The forest conservation department addresses the problem of deforestation and land use changes.

The second division supervises conservation and is headed by an Additional Secretary (of administrative service cadre); this division also administers various other conservation programmes in addition to forests (like wetland, biodiversity etc.). The Additional Secretary reports to the DGF for forest conservation (called eco-development and regeneration programmes) related issues and to Secretary in the Ministry for all other conservation programmes. The third department under the DGF administers the protection of wild life and maintains zoos and national parks.

The multiple actors and plethora of bureaucracy at both central and state levels with a mix of generalists and those with specialised knowledge of forestry described above has not helped in the conservation of forest cover. The central bureaucracy formulates policies often, without proper understanding of ground realities owing to its remoteness. Again, uniformity in policies may not be appropriate in a large and diverse country like India. The state bureaucracy has to deal with the central directives besides its own rules and regulations. It is also constrained by the nexus of contractors and politicians and often, become a part of the axis. Thus, the 
coordination cost of forest conservation has been high and not surprisingly, the policies and institutions have led to steady decline in the forest cover in the country.

The central government introduced the Forest (Conservation) Act in 1980 in response to high rate of deforestation. The act required that the state governments would have to obtain prior permission from a central committee in the Ministry called Forest Advisory Committee, headed by the DGF, for conversion of forest land. Thus, the government's response to the declining forest cover has been to centralise decision making through increased monitoring and control. However, the deforestation problems were not due to non-optimal decisions by state governments. The problem lies in the structure of incentives to the state level bureaucrats and their incapacity to prevent quasi-legal or illegal logging activities or connivance with the contractors. In such cases increased central control would do nothing to tackle the root cause. Instead, more effective local monitoring through community and local government involvement, would be an appropriate policy response. Thus, it is not suprising that the act failed to check deforestation and the government finally had to opt for a decentralised governance structure by involving communities for forest protection and creating the institution of joint forest management in 1990.

\section{Stakeholders in the Forest Sector of India}

Role of Central and State Governments: The transfer of "forest and

wildlife" from the state list to concurrent list in the constitution has given the central government overriding powers in formulating policies and promoting and coordinating programmes. The Ministry of Environment and Forests formulates overall policy framework. However, implementation of measures to protect forests is the responsibility of the states. Besides, as revenue from forests accrue to the state governments, the interests of the central and the state governments do not necessarily coincide, and the centre is arguably able to take a more long-term view. Politically, the centre responds to groups that are well represented in the national capital, particularly, conservationists, international agencies, and voluntary groups have a considerable influence on the direction of policy at this level.

The responsibility for forest protection, management, and utilisation rests with the states. The constitution also assigns the revenues from the 
forests to the state governments. Being closer to decision makers, regional and local interests influence formulation and implementation of regulatory policies on sustainable forestry. Furthermore, interest of revenue could result in poor enforcement of regulations relating to the protection of forests. These have led to judicial interventions, which will be discussed below.

Other Stakeholders: An important institution for the regulation and development of forests is the bureaucracy. The bureaucracy consists of field level officials of the State Forest Departments and decision-makers at the policy level. They are responsible for the day-to-day management of state forests, and has maximum direct interaction with user groups. They have enjoyed considerable freedom of action in implementation because existing forest legislation gives them a great deal of discretionary control over the flow of benefits from state forests. However, in some case interference by politicians considerably constrains their ability to act independently (Vira, 1995).

Within rural society, it is possible to distinguish groups by the extent and nature of their dependence upon natural resources. The dependence of medium and large land owning groups on common resources is typically mediated through the market. Small and marginal farmers and the landless rural resource users depend on local commons for subsistence needs - fuel, fodder, food, and basic construction timber.

Other stakeholders include manufacturers of forest-based products and contractors. Restrictions on logging has made forest based industry unviable. At the same time, forest contractors have been a strong force in preventing its effective implementation. Trade in nontimber forest products (NTFP) has been controlled by private contractors, who on the one hand depress wages to subsistence groups to make large profits, and on the other exploit both the forests and indigenous people living in forest. Despite the pronouncements by the National Forest Policy Resolution, 1952 and reiteration by various policy pronouncements including Plan documents, contractors remain an exploitative force in forestry operations due to their strong political links and connivance with forest bureaucracy. (Guha, 1983).

The Forest Act allows the state to delegate the management of some forests, designated in such cases as village forests, to village community organisations. In practice, the weakness of local government institutions has meant that such assignments were very limited, or 
useless in effect. While this situation may change in the long run, with the strengthening of local governments (Wade, 1988, ch. 13), it will require state governments' decision-makers (politicians and bureaucrats) give up significant source of rents. As documented by Wade (1988) in the case of irrigation, different levels of the bureaucracy and political structures also collude, and share the rents acquired from those who are given access to the resource (water or trees, as the case may be).

\section{Features of Decentralisation ${ }^{5}$}

The increasing depletion of India's forest resources has brought into sharp focus the inherent inadequacy of traditional state-owned and operated systems of forest management in sustaining the forest resource base against the growing human and livestock population pressures, industrialisation, and urbanisation. Apart from developmental pressures, the dependence of forest user groups is a crucial factor in the state of India's forests. Forest conservation priorities cannot be determined in isolation from local people and broader patterns of natural resource use, and this must be complimented by policies promoting sustainable and equitable development of the natural resource base as a whole. In acknowledging this factor, the Ministry of Environment and Forests, Government of India issued policy guidelines for the involvement of village communities and voluntary agencies in the regeneration of degraded forest lands on June 1, 1990 under the JFM (joint forest management) programme.

Under the JFM programme, the user (local communities) and the owner (government) manage the resource and share the cost. The effective and meaningful involvement of local communities in evolving sustainable forest management systems allows the use of indigenous knowledge about different aspects of conservation. It is well known that rural people particularly women and indigenous tribes (also referred to as tribals), have intimate knowledge of species, their growth, utility and medicinal value. The linking of incentives and participatory forest development has been singularly instrumental in eliciting community participation.. Currently, it is estimated that 10.24 million hectares of forest land are being managed under the JFM programme through 36,075 village forest committees (VFCs) in 22 states..

Following the launching of the JFM programme in India in the last decade, several issues of importance have emerged like the 
diversity in institutional and benefit-sharing arrangements, development of technology and silvicultural practices to increase the productivity of degraded forests, etc. In the current arrangement people's needs have taken centrestage. As a result silvicultural practices and technologies now need to be oriented to not only increasing forest productivity but also to the management of NTFP (non-timber forest products), fodder, and fuel-wood.

A review of the institutional and benefit-sharing arrangements across states that have implemented JFM has caused some serious concerns. These include inadequate funds and arbitrary allocation of the available funds, inadequate personnel to supervise, lack of coordination between the administration and field staff, non-existence of a structure of governance to coordinate the working of VFCs with other departments to avoid a multiplicity of committees within a village. The functioning of these committees under the panchayats (local governments) is also not well defined. Thus, existing legal and policy provisions relating to forests, revenue lands, rights and concessions, customary laws, traditional rights, resolution of conflicts and coordination between rural local governments and JFM lacks a clear framework. There are also a plethora of ambiguous and often conflicting resolutions, laws, policies, and acts. This leads to ambiguities and uncertainties, creates scope for supersession on the basis of legal technicalities. Certainly, greater coordination efforts are required among rural development and forest ministries of the state and central governments.

Despite a reasonably successful attempt in introducing decentralised and participatory management of forests thorough JFM, the success of the programme depends on the way in which the forest department and more particularly, the Divisional Forest Officer (DFO) exercises his powers. In fact, the role assigned to the DFO is pivotal in the initiation and success of the JFM programme. With powers to disband a badly functioning committee, cancel membership, and nominate NGOs for membership, the relationship has been criticised to be unequal and the actual power seem to be retained by the state bureaucracy. It must also be mentioned that the JFM has been launched only in areas where natural forests are already lost and local communities require help to restore forest cover and achieve (or regain) a more sustainable forest management system. Ironically this has meant that those communities which have not significantly depleted their forests do not qualify for the programme. 
In many areas, indigenous people have felt excluded from JFM because opportunities to participate have been monopolised by higher caste and elite groups who have been able to use their greater access to officials to secure participation in the JFM scheme. The marginalised and technically landless groups like the tribal peoples have thus seen 'degraded lands' and 'wastelands' that were important to their livelihoods annexed to JFM, leaving them further impoverished.

\section{Intervention of the Judiciary}

Despite recent efforts to increase forest cover through reforestation, there has been considerable depletion of the forest cover in India, and at present, the forest cover comprises less than 18 percent of total land area. The actual forest area with crown density is only about 11 percent. Despite legilslations and allocation of financial resources, the forest area of the country instead of showing an increase has continued to deteriorate. According to the State of the Forest Report, 1997, between 1995 and 1997 more than 17,000 square kilometers of forest land was lost. Concerned with the rapid depletion of forest cover throughout the country, the Supreme Court in 1996 directed that all "ongoing activities in any forest in any state" should be stopped forthwith. It said no activity should be carried out without the prior permission of the central government under section 2 of the Forest Conservation Act, 1980. Every state was directed to ensure immediate compliance of the direction and report to the court within two months.

As regards tropical rain forests in Arunachal Pradesh in the districts of Tirap and Changlang, a complete ban on felling of trees was imposed. A complete ban (with the exception of defence and other government purposes) was also imposed on the movement of trees and timber from any north eastern state to any other state. In 1998 the Supreme Court gave detailed order on pricing of timber, licensing, forest protection, management of forests, wood based industries and possible action against officials for neglecting duty or indulging in corrupt practices. The court instructed all the states with rich reserve of forest on the steps to be implemented to check deforestation (Shyam Divan and Armin Rosencranz, 2001)

However, the decision of the Supreme Court has placed hardships on a number of state governments both in reducing the 
revenue earnings and in constraining forest resource based economic activity, many thought these ad hoc measures are fraught with danger, they can spin out of control unless the procedures are institutionalised and governed by suitably formulated laws and policies.

The court's action has been effective in producing results. The latest statistics from the State of the Forest Report actually show a net increase in the forest cover by $3,896 \mathrm{sq} . . \mathrm{km}$ in the forest area assessment held between 1997 and 1999 and a further increase of 38,245 sq. km between 1999 and 2001.Nevertheless, the appropriate course of action seems to be to have a sustainable plan for forestry rather than persist with blanket bans.

\section{Environmental Regulation in India: Water}

\section{Evolution of Policy}

The first national policy on water was formulated in 1987. The government felt that as the country prepared itself to enter the $21^{\text {st }}$ century, effect to develop, conserve, utilise, and manage water resource have to be guided by national perspectives. The policy makers realised that water is a scarce and precious national resource that needs to be planned, developed and conserved as such, and on an integrated and environmentally sound basis, keeping in view the needs of the growing population. The second national policy on water was formulated in 2002. The two national policies dealt with all-important aspects of water usage, conservation, and regulation.

\section{The Assignment System}

As discussed earlier, the responsibility of developing and managing the water resources has been distributed among the central, state and local governments in India. These responsibilities have been further delegated to different ministries, their departments, agencies, and commissions. The Union Ministry of Water Resources formed in 1985 is in charge of overall planning, policy formulation, coordination and 
guidance, development and regulation of water resource in the country. Prior to 1985 the focus on water related issues were mainly on irrigation, command area development, flood control, and ground water exploration. The formation of the ministry gave a new thrust to programmes on water and a comprehensive policy was developed for the first time in 1987.

The functions of Water Resources Ministry overlap with several other ministries since water has multidimensional aspects and uses. The Water Resources Ministry has to coordinate with the Ministry of Agriculture for the development of watersheds ${ }^{6}$ and drip and sprinkler irrigation systems. The Central Water Commission in the Water Resources Ministry has to maintain close technical links with the Ministry of Power for the development of hydroelectricity. In matters related to water pollution, the Ministry has to coordinate with the Ministry of Environment \& Forests and the Central Pollution Control Board since these organisations are responsible for maintaining the quality of water. The ministries of Rural Development and Environment and Forest also have programmes for watershed development. In addition, the Ministry of Rural Development is responsible for a "Million Wells Scheme" under which development of ground water is taken up. The National Drinking Water Mission is also under the Ministry of Rural Development and it is responsible for developing the source of drinking water in rural areas. ${ }^{7}$ The Ministry of Industry is concerned with the planning and development of water resources for industrial use, Ministry of Urban Development for drinking water in urban areas, and the Indian Council of Agricultural Research is responsible for research on water management techniques. The Ministry of Water Resources, being the nodal agency on issues related to water, needs to closely coordinate with all these ministries to ensure maximum utility from water use.

The involvement of multiple agencies for administering water use requires a well-coordinated system of governance. The Ministry of Water Resources, which is the nodal agency, has a Secretary as its administrative head. He has several commissioners below him looking after various departments like policy planning, projects, Indus Water Treaty, command area development and water management, matters related to eastern rivers, hydrology projects and minor irrigation. The Secretary is also assisted by a financial and a coordination and evaluation advisor. 
There are other organisations in the Water Resources Ministry which have been delegated responsibilities related to important aspects. These are (i) Central Water Commission, a premier technical organisation in the country in the field of water resources and is charged with the general responsibilities of initiating, developing, and coordinating schemes for control, conservation and utilisation of water resources for purposes of flood control, irrigation, navigation, drinking water supply and water power development in consultation with the state governments; (ii) The National Water Development Agency was set up in 1980 to promote scientific development for optimum utilisation of water resources and for preparing feasibility reports for inter-basin transfer of water; (iii) The Central Ground Water Board is entrusted with the responsibilities of hydrogeological surveys, exploration, assessment, development and management of ground water resources. In addition to these national level organisations, there are river boards to look after specific river basins. Organisations such as Water and Power Consultancy Services (India) Limited and National Projects Construction Corporations Limited, provide technical services for development of water resources. Institutions like National Institute of Hydrology, Central Soil and Materials Research Station provide scientific inputs on water development.

As mentioned earlier, in accordance with the constitutional provisions some aspects of water use, regulation and development are under the charge of the state governments. They implement two types of schemes, those with a 100 percent grant from central government and those in which the states share the cost. Within States the Department of Irrigation is in charge of developing and maintaining irrigation projects as well as groundwater development. The departments of panchayati raj (local government) and rural development, the departments of environment and forests and science and technology and the departments of agriculture implement watershed development programmes. In addition the department of finance and planning oversees the work of the remote sensing agencies in different states, which is in charge of investigating and proposing areas in the states for water management, afforestation etc.

Historically, government institutions have been formed on departmental lines rather than a coordinated vision of resource development. They follow narrow sectoral objectives without reference to other departments working in same area and related sectors. Most state departments of agriculture do not deal with water at all even though 
agriculture consumes largest volume of water. Further, there seems to be disjunction of institutional responsibility between state and local governments. In many states, the institutions related to watershed based poverty alleviation programmes or drought prone area programmes do not have any local presence and the involvement of local people does not exist. ${ }^{8}$

Another major problem in development and regulation of water resources is the plethora of bureaucracy to administer various aspects of water resources management involving heavy coordination cost. A Secretary heads the irrigation department of the state governments. He is assisted by a number of bureaucrats including the director of groundwater who is usually a hydrologist or a geologist. The irrigation projects at the state level are headed by a chief engineer, who delegates responsibilities to the Superintendent Engineers functioning at the district level. The Superintendent Engineer is advised by a District Irrigation Advisory Committee headed by the District Collector, who is the chief administrator of the district. At the village level (where there are existing irrigation structures or new ones being initiated) there is usually a departmental worker who liaisons with the water users' associations (which is an elected body of the village) and report to the works inspector belonging to the engineering department.

At the state, district, and village levels, several departments are involved in water resource management. At the state level, the Secretary from Panchyati Raj ministry supervises water conservation missions, rural water supply, and minor irrigation. The State Pollution Control Boards are responsible for monitoring water pollution and quality. The Department of Forest and Environment implements afforestation and watershed projects. The state remote sensing agencies which collect data on the availability of water, investigate and propose new areas for water management.

At the district level the District Collector is the Chairperson of District Irrigation Advisory Committee and is also the Chairperson of the District Watershed Advisory Committee. He/She is assisted by a Project Director implementing projects related to watershed development. The Chief Executive Officer of the Zilla Parishads (District Legislative Assemblies) sanctions funds for rural water supply networks and these are constructed and maintained by the engineering department of the district headed by a Superintendent Engineer. All districts usually have 
an Environmental Officer functioning under the directive of the State Pollution Control Board on matters related to water pollution.

In the villages, there are Gram Panchayats (village local governments) with an elected head called sarpanch who is also the chairman of the water conservation and utilisation committees, watershed committees/associations. Many states have community facilitators, social mobilises and common interest groups working in coordination with the Gram Panchayats. Some villages also have elected water user's associations working directly with the works inspectors of the irrigation department of the states.

Thus, on paper the assignment of environmental power in Indian federalism is reasonably clear. Broadly, while the central government has the responsibility of determining the overall policy frame, the subnational governments are involved in implementation. Thus, the assignment system attempts to minimise transaction costs by providing sufficient scope for decentralised governance of environmental functions. However, the implementation of environmental functions has been a major concern. In most cases, a critical factor impeding effective implementation is the structure of incentives to bureaucracy and policymakers and influence of politicians on them. Besides, the environmental regulators do not have access to modern technology and the resources with them are inadequate.

\section{Issues in the Water Sector: Coordination Failures}

Inter State River Water Disputes: A close scrutiny of Indian waterdispute settlement mechanisms shows that these are ambiguous and opaque. The problems are compounded by the entanglement of inter-state water disputes with more general centre-state conflicts, and with everyday political issues. These impacts can be reduced by a more efficient design of negotiating mechanisms. However, as large areas of India are relatively arid, water is critical to the welfare of the country's citizens and obviously, evokes a lot of emotions.

Because India is a federal democracy, and because rivers cross state boundaries, instituting efficient and equitable mechanisms for allocating river flows has long been an important legal and constitutional issue. Numerous inter-state river-water disputes have erupted since 
independence. An example of the intensity of conflict relating to Cauvery river water involving the southern states of Karnataka and Tamil Nadu may be seen from the following incident:

"A farmer jumped to his death into the Kabini reservoir on Wednesday (September 18, 2002) to protest against Karnataka's decision to release Cauvery waters into Tamil Nadu." .....As news spread ... spontaneous protest marches were held with 300 farmers courting arrest in Mandya" (www.rediff.com, September 19, 2002.

This particular dispute continues to remain unresolved and no solution acceptable to all the parties seems possible within the existing arrangement.

The phenomenon of inter-state water disputes in India is still relatively less understood. Part of the difficulty is the plethora of actors and the complexity of the institutional environment within which the various parties reach (or fail to reach) agreement. Actors include state governments (which in turn must be decomposed into professional politicians, political parties, and interest groups), the national parliament, central ministries, the courts, and ad hoc water tribunals. In general, riverwater disputes have involved state and central politicians, as well as the courts and special tribunals and commissions set up to arbitrate. Although fairly explicit constitutional provisions govern inter-state river waters, it is unclear precisely whether existing mechanisms for adjudicating interstate water disputes are adequate. Indeed, there is growing consensus that existing institutions are increasingly unable to generate acceptable outcomes that contribute to economic growth and national welfare.

Numerous inter-state riverwater disputes have erupted in India since independence. The disputes persist even as they have proved costly and the existing dispute resolution mechanisms are ambiguous, opaque and in many cases flawed (Rao and Singh, 2004). In a cooperative bargaining framework water can be shared efficiently, with compensating transfers as necessary, if initial water rights are well-defined, and if institutions to facilitate and implement cooperative agreements are in place. However, when the initial allocation of rights is at stake and where the parties face a situation of pure conflict rather than one of potential gains from trade, a search for a negotiated solution may be futile, and quick movement to arbitration or adjudication may be more efficient. However, in 
the Indian case, not only is this process slow, but also effective binding arbitration does not exist.

Water and Indian Federalism: Indian institutions for water-dispute resolution are ambiguous and opaque. State governments dominate the allocation of river waters. The Inter-State Water Disputes Act of 1956 was legislated to deal with conflicts, and included provisions for the establishment of tribunals to adjudicate where direct negotiations have failed. However, states have sometimes refused to accept the decisions of tribunals, so arbitration is not binding. Significantly, the courts have also been ignored occasionally. The centre has sometimes intervened but in most complicated cases, it has been not succeeded. In short, an effective institutional mechanism for settling inter-state water disputes does not exist.

The relevant provisions of the Indian Constitution are (i) Entry 17 in the state list, (ii) Entry 56 in the union list, and (iii) Article 262. Essentially, Indian federalism with a strong centripetal bias has consistently involved coalition building. This has meant a high level of explicit or implicit "horse-trading" among the centre and states that are potentially key elements of a central coalition One possible interpretation, therefore, is that the centre wishes to preserve a system, which allows it flexibility or discretion in bargaining over centre-state issues in general, with water being one of them. A related feature of Indian political economy is the problem of multiple vetoes (Bardhan, 1984; see also Singh, 1997), which would help explain why, with discretion preserved, it may not be used decisively. This, too, seems relevant to the case of water, where negotiations have dragged on, and where the central government has sometimes prolonged them, by failing to speedily appoint a tribunal, even when asked.

Disenchantment with the adjudication process for inter-state river disputes led to several attempts at change. First, the National Water Development Agency was created in July 1982, to "carry out the water balance and other studies...for optimum utilisation of water resources..." (National Water Development Agency, 1992). This is an institution set up by the Government of India without any statutory backing. Furthermore, its scope is technical, and separate from the institutional realities of water allocation. Second, in 1983, the National Water Resources Council was created by a central government resolution. Its composition includes chief ministers of states, lieutenant governors of 
union territories, several central government ministers, and the Prime Minister as chairman. This group met first in October 1985, and adopted a National Water Policy in 1987. Unfortunately, however, disenchantment with the adjudicative process for inter-state river disputes has continued.

In summary, the resolution of water disputes is complicated by being tangled in the general difficulties of centre-state federal issues. The wide scope for discretion, the extensive bargaining, and the multiplicity of potential vetoes work in tandem to undermine the clarity and transparency needed for speedy dispute resolution. In May 2002, the ISWD Act was amended to try to place time limits on tribunals:

Analytical Foundations of Water Disputes: Economic analysis offers helpful guidance to understanding the problems of inter-state water disputes. Admittedly, water has a number of features that create potential market failure. These may include non-rivalry, nonexcludability, externalities, merit good features, and significant transactions costs (Richards and Singh, 2001). The presence of these factors means that although increased reliance on market forces (e.g., one state selling water to another) can contribute significantly to resolving water issues, there is no escape from the need for parties to agree upon a set of rules, an enforcement mechanism, and a prior distribution of property rights.

Property rights have been claimed on the basis of historical use, as well as on the basis of the Harmon Doctrine, that "what falls on our roof is ours to use, without regard to any potential harm to downstream parties". Historical use can work against trading water rights, while the Harmon Doctrine ignores externalities as well as past investments connected with water use. A third approach, that of the social contract a la Thomas Hobbes, holds more promise. A deal must be struck among the existing decision-making entities, such as Indian states, which (i) decides on an initial allocation of property rights and (ii) creates a mechanism to trade these rights, to regulate uses that generate externalities, etc. Consequently, institutions that support efficient bargaining and can enforce binding agreements are essential.

The obvious starting point for thinking about bargaining over water is the Coasian perspective (Coase, 1960). Coase's ideal bargaining solution provides a benchmark against which one can 
compare reality. The main lesson of Coase is that one should not presume that central intervention is desirable or necessary in inter-state water disputes. Indeed, when the essential problem faced by states or groups within a state is that the initial allocation of water is sub-optimal due to changing circumstances, cooperative bargaining will lead to an optimal allocation. However, there are (at least) three situations in which bilateral or multilateral bargaining among concerned state governments may not be efficient or equitable on their own.

- When the centre can affect starting positions or threat points in the bargaining game between states.

- When there is incomplete information, even imperfect central intervention can be better in expected terms than bilateral bargaining. There are potentially two kinds of information: technical and subjective. In principle, technical information may be shared and verified, but in practice this can be very timeconsuming, and contribute to lengthy proceedings, as is typical of Indian water tribunals. Complicating matters further is the way costs and benefits are truly evaluated subjectively is often not objectively verifiable. When a rival's objectives are unclear, bargaining becomes far more difficult.

- When there are multiple issues to be bargained over, there may be spillovers to non-riparian states.

An additional complication is that the productivity of a given quantity of water depends on the level of complementary investments (Richards and Singh, 1996,). These may include dams, irrigation projects, or even more general complementary investments in agriculture. The first thing to note is that as long as the benefit from a given amount of water is dependent on the amount of investment, the optimal allocation of water will depend on the investments in both states. Hence, even though there are no direct externalities as a result of the investment, the conditional optimum of water allocation involves a linkage of both states. What state $A$ does with its investment will affect the optimal amount of water that state $B$ should receive. This was an important ingredient of the Cauvery dispute.

This analysis assumes that property rights over water are well specified and clearly understood. But this may not actually be the case. In fact, much of the conflict or disagreement over inter-state river waters in India as an attempt to influence or determine the initial allocation of 
property rights over water, is by methods such as political lobbying. The initial quantities of water are not given, but are precisely the main subject of negotiations. In some cases, there is a de facto allocation of rights based on historical usage, but there is a surplus of currently unutilised water that can be used (often only if appropriate investments are made) once it is unambiguously allocated. It is critical to recognise that in such cases, the situation is one of pure conflict: more for one party means less for another when there is a given total amount of the resource.

In India it is specified that if negotiations fail, a tribunal must be appointed. However, this is done at the discretion of the centre and, in the above situation, the centre would actually prefer a political solution, where it barters an award for political support. Reducing discretion, such as specifying short time limits for negotiation, with a tribunal to take over thereafter, is essential in such a situation.

Groundwater: Nearly 85 percent of groundwater exploited is used only for irrigation. Besides, groundwater is now the source of fourfifths of the domestic water supply in rural areas, and around half that of urban and industrial areas. Further, in drought years, it is the predominant source of irrigation. Not surprisingly, the overuse of groundwater is emerging as a major concern. A burgeoning population is overdrawing aquifers in several states. The latest data indicates that in the states of Punjab, Haryana and some urban areas water tables are falling by up to 1 metre per year. Although at the national level, only 30 percent of the actual groundwater potential has been harnessed, in states such as Punjab, against a critical level of 80 percent, the level of exploitation is over 98 percent. Haryana is a close second at 80 percent, and Tamil Nadu is reaching criticality at 60 percent. Within states there are pockets that have reached a very critical condition with respect to groundwater utilisation, sometimes exceeding 100 percent. Large cities like Ahmedabad, Jodhpur, and Chennai support thriving private groundwater businesses that draw water from tubewells in the neighbouring hinterlands for supply to high-income residential areas, because groundwater tables in the cities are falling at a rate of 7-10 feet per year. Besides depletion, pollution of aquifers through human activity constitutes another major problem.

Most groundwater structures are privately owned, and therefore, are outside the purview of direct state regulation. Measures to regulate groundwater extraction chiefly through restrictions on credit or electricity 
have had limited impact. On the contrary, wherever the water table is high, affluent farmers use diesel pumps if electricity is in short supply. In the legal framework, for the management of groundwater in India, there are no de jure rights to groundwater; de facto, all landowners have the right to the groundwater in their land. Thus, groundwater is viewed essentially as an add-on to the land. As a consequence, there is no limit to the amount of groundwater a landowner can extract from his land.

Concerned at the critical situation with regard to groundwater the Supreme Court constituted the Central Ground Water Board (CGWB) as Central Ground Water Authority (CGWA) to regulate and control ground water management and its indiscriminate boring. The authority has assessed that 310 out of 5711 blocks in the country have reached a critical situation where the rate of withdrawal is more than the rate of replenishment and another 160 blocks are approaching such a situation. The authority has further declared several regions as notified areas for the protection and preservation of ground water resources. In such areas, extraction of ground water without prior approval of the authority has been prohibited. The authority has also organised mass awareness campaigns at various locations in India.

Another problem related to groundwater is the pollution and contamination of aquifers due to over-exploitation, see page of sewer lines, disposal of chemical effluents in natural watercourses, salinity ingress in coastal areas and natural formation of arsenic, fluoride and iron. It is difficult to restore ground water quality once the aquifer is contaminated. The CGWB is mandated to develop cost effective technologies like solar stills for purifying contaminated groundwater.

It is pertinent to point out here that development and monitoring of ground water needs to be done at the local level since it is the local people who use it. The cost of monitoring and generating information by a central agency like the CGWB / CGWA on groundwater at the local level is higher than a local level institution like panchayat in villages or municipalities towns and cities. Moreover, ground water development plans need to be coordinated and integrated with watershed development plans which should have a specific component of ground water recharge by developing check dams. However, the watershed development programmes are planned and implemented by several central and state agencies ${ }^{9}$ who function independently from the CGWB/ CGWA. Further, at the district level there are advisory committees and at 
the village level too there are committees but there is no mechanism to coordinate among the plethora of actors and institutions. Ironically, there is an institutional disjunction or vacuum in spite of the existence of several institutions.

Surface water and Irrigation: India's irrigation system is not performing anywhere near optimum capacity. The irrigation efficiencies are notoriously low, at around 35 percent. A number of projects suffer from time and cost over-runs for want of adequate financial resources for completion. The completed projects are in a poor state of maintenance as the emphasis is on new projects rather than properly maintaining the existing ones. The consequence of such a poor state of maintenance has resulted in three-fold increase in waterlogged area, from 7 million hectares in 1976 to 23 million hectares in 2000 .

In order to utilise the capacity created by the irrigation structure, the Command Area Development Programme (CADP) was launched in 1974-75 by the water resources ministry of the central government. It was found in the evaluation studies of the ministry that the progress made in the construction of field channels was inadequate due to lack of funds. It seems difficult to carry on this programme without the involvement of the stakeholders like water users' association and private sector participation. The private sector has kept away from irrigation projects due to high unit cost of development (US \$2200/ hectare), high gestation lag and the attitude of irrigators who are often not used to treating irrigation as a commercial service.

The Participatory Irrigation Management Scheme administered by the Irrigation Department of state governments will be effective in easing the resource crunch being faced by the CADP. There is a lot of merit in coordinating the two programmes since they overlap in the same space, as also they will promote mutual accountability between the water users' association and the irrigation department

The CADP also envisaged integrated and coordinated development of irrigated areas along with on farm development. However, coordination failure between the Agricultural Department of the states which provided extension support services for on farm development and Water Resources Ministry which developed the command area resulted in a mismatch between the place and time where the extension service and irrigation was provided. 


\section{Features of Decentralisation}

Watershed Development and Tank Irrigation: One of the most undesirable features of development is that the traditions of water harvesting and tank irrigation have shown a decline in the states. Neither the government nor the people have taken any initiative to preserve them. While the central and state governments have focused construction of big dams and large networks of irrigation, people have resorted to measures like groundwater mining through tube wells (e.g. Tamil Nadu, Maharashtra, Andhra Pradesh). According to lyer (2003) it may not be easy to revitalise these structures since the land use pattern has changed irreversibly. A more comprehensive watershed development approach is called for rejuvenating the local systems. With the constitutional recognition accorded to rural and urban local governments in the $73^{\text {rd }}$ and $74^{\text {th }}$ amendment to the constitution, the local bodies have been empowered to maintain such structures. There has also been a realisation about the utility and sustainability of small locally managed water-harvesting systems with involvement of the people at the local level.

The paradigm of watershed development was initiated in India in the 1970s in the state of Haryana due to scarcity of water. Subsequently such local level initiatives were replicated in the states of Mahrashtra, Madhya Pradesh, and Rajasthan. Studies have shown that that most of these initiatives have led to an increase in water availability and a noticeable increase in agricultural production (lyer, 2003). The water harvesting structures also contributed to water recharge to the ground water aquifers that enhanced the availability of drinking water. The incidence of benefit varied across groups, most benefits accrued to the landed class with large land holdings, benefits to landless labourers and cattle grazers were not direct and assured. There is also an element of capture by the local elite even in this paradigm of development. A recent study based on primary data in the states of Karnataka and Uttaranchal has found that the local elite has benefited more than the poor (Rajashekar, 2004).

The country has begun to take rainwater harvesting and groundwater recharge seriously at all levels under the massive integrated watershed development programme. Trends during the 1990s 
also suggest a progressive shift of budgetary allocation from irrigation development to water harvesting and recharge. Across India, some 6.2 million hectares of rain-fed lands are currently under treatment through 5,200 micro-watersheds at a whopping cost of Rs 8 billion (200 million \$) for the year 2001-2002.

Water Users Association: In India disappointing performances of government owned and operated irrigation systems mainly owing to poor cost recoveries have compelled a number of states like Maharashtra and Andhra Pradesh to transfer rights and responsibilities for management of irrigation systems from government agencies to private or local persons or organisations. Transferring responsibilities has come to be seen as a way to reduce pressures on thinly stretched government finances while at the same time improving irrigated agricultural production and ensuring the long term sustainability of irrigation systems (Geijer et. al., 1996; Vermillion, 1991). The intention is to encourage local initiative to take responsibility for the management of resources in the belief that beneficiaries have greater stake and better information for making efficient resource allocations (Brewer et. al., 1997). Some states like Karnataka and Maharashtra, have formulated a clearly defined and codified policy, called participatory management, of promoting transfer of irrigation management responsibilities from the government to farmers.

Preliminary results indicate that, in the proper environments, participatory management increases efficiency of water use and the value of irrigated agricultural production. However, benefits accrue mostly to the elite and the whole system is managed and operationalised by this group.

\section{Water Pollution}

Waste Disposal in Rivers: Waste disposal in rivers is a big problem in India. As an illustrative case, we take the river Yamuna on which the capital city of Delhi is located. Delhi discharges more than two thousand million litres per day (mld) of wastewater into Yamuna river. Of this about $300 \mathrm{mld}$ is contributed by the industrial sector and a bulk of the pollutant comes from the untreated sewage because the city administration lacks funds to install sufficient sewage treatment facilities. A report published by Delhi Pollution Control Committee (1993) reveals that a mere $31.8 \mathrm{mld}$ of sewage is treated sufficiently for disposal into the 
river. The sewage goes untreated into the river during machinery and power breakdowns, in other cases badly silted plants get flooded during rains. As a result, though Delhi covers only two percent of the length and basin area of the river, it contributes 71 percent of the wastewater discharged into the river! And since most of the Yamuna waters that flow into the city are used up to cater to Delhi's requirements, what remains of the river after Delhi is undiluted sewage. Asphyxiation of Yamuna begins right from the entry of the river into the city, there are 18 notorious drains and ends up in the river at various points along the $22 \mathrm{~km}$. stretch through Delhi. Industrial waste from Delhi's industries flow through these drains. By the time the river leaves Delhi the water is not fit for even bathing. The situation is worse during summer. The average annual flow in Yamuna is estimated to be about 100 billion kilolitres of which 80 percent is during the three monsoon months. With very little water flowing through it during the other months, the assimilation capacity of the river is considerably reduced - the river dies and turns into sewage flow channel.

The story of Yamuna is not unique; in fact, the entire river system in India is grossly polluted. Industries, municipal corporations, government agencies and almost everyone is responsible for polluting the river system. There is consciousness about polluted rivers and several laws have been enacted to provide legal backing for cleaning up the system. The Ganga Action Plan (to reduce pollution in the Ganges and its tributaries) and Yamuna Action Plan (YAP) was launched in 1984 and 1991 respectively. However, several studies conducted by National Environmental Engineering Research Institute (NEERI) and Indian Institute of Technology point out that these Action Plans have not really reduced the level of pollution in the rivers (Shyam Divan and Armin Rosencranz, 2001). ${ }^{10}$

\section{Environmental Regulation: Controlling Urban Air Pollution}

The living conditions of millions of urban population are such that they pose a threat to their health and have potentially catastrophic social consequences. For the urban poor, living conditions are the worst. 
Burgeoning urban population beyond the carrying capacity of the different components of urban eco-systems, coupled with indifferent urban governance, are the root causes for urban environmental problems. The blood lead levels of persons in Ahmedabad, Bombay, and Calcutta have been reported to be higher than the corresponding levels of persons in lead-free gasoline areas. In most of the cities, the SPM levels are significantly higher than the CPCB standards.

The deterioration in air quality in most Indian cities has led to an intense search for ways of controlling pollution. Tentative estimates of health costs of urban air pollution in India is US \$ 1.4 billion (Brandon and Hommann, 1995). ${ }^{11}$ Vehicular emission is a major source of air pollution. For example, in Delhi, where health incidences and cost of air pollution is the highest in India, contribution of vehicles to the daily emission level is also the highest.

Control of air pollution has to factor in to the growth in the number of vehicles, congestion, poor quality of roads, and quality of fuel used in vehicles. Though the history of legislation for maintenance of air quality starts with the Air (Prevention and Control of Pollution) Act, 1981, it was the Environmental (Protection) Act, 1986 that prescribed emission standards for vehicles for the first time. The prescribed standards pertained to the emission of carbon monoxide and hydrocarbons. The act proposed to implement the standards in 1992. The responsibility of enforcing these standards was vested in the Ministry of Surface Transport (MoST).

In 1989, the Motor Vehicles Act of 1939 was amended and the Idle Emission Regulation was enacted. In April 1990, these rules were notified to vehicle owners. The rules made it mandatory to obtain a certificate of fitness for registration of public, commercial, and private vehicles older than 15 years. The rules also required all motor vehicles to comply with the laid down emission standards and obtain a certificate of 'pollution under control' (PUC). However, the whole system of issuing the certificates needs more credibility and accountability, as a result the maintenance of vehicles in most cases is very poor specially in relation to pollution control. The certification authorities need to involve stakeholders like Resident Welfare Associations in the urban localities where such problems exist. At present the PUC certification is being carried out by the motor vehicle inspectorate, know as Regional 
Transport Offices (RTOs) attached to the transport department in each state.

In 1991, Mass Emission Regulation was introduced. The legislation laid down emission standards of pollutants under specified driving conditions for vehicle manufacturers as well as for in-use vehicles. The emission rates of vehicles were checked during mass emission tests. In 1995, fitment of catalytic converters (CAT) for cars in the four metros was made compulsory. The mass emission standards were tightened in 1996 to improve the effectiveness in producing the desired result. Evaporative Emission and Crank Case Emission Regulation was introduced and emission limits of $\mathrm{CO}, \mathrm{HC}$ and $\mathrm{NO}_{x}$ were lowered.

\section{Intervention of the Judiciary}

Introduction of strict norms by the administration of the Union Territory of Delhi did not make any difference in controlling vehicular pollution. The quality of air continued to deteriorate in Delhi, citizens found the pollution unbearable with eye and lung problem increasing sharply around mid-nineties. On July 28,1998 , in response to a public interest litigation, the Supreme Court of India ruled that all eight-year-old buses and pre-1990 three-wheelers and taxis would have to be converted to use compressed natural gas (CNG) by March 31, 2000. For the remaining buses, three-wheelers and taxis, March 31, 2001 was fixed as a deadline. This order, however, was difficult to implement. However, the Supreme Court took a strong stand and forced the Delhi Administration to implement the programme of converting the diesel run buses to use CNG fuel and despite strong opposition by various lobbies and reluctance of the government, the programme had to be implemented. Thus the judiciary, instead of the executive, took the onus of implementing pollution control measures.

In May 1999, the Supreme Court of India directed that Euro-I emission norms would be effective for the National Capital Region (NCR) for registration of all private (non-commercial) vehicles with effect from June 1, 1999 and Euro-II norms with effect from April 1, 2000. The apex court passed these directives after detailed consideration of various options recommended by the Environmental Pollution Authority (EPA). Following the Supreme Court directives, India 2000 norms were formulated in the year 2000 . These norms are significantly tighter than the mass emission standards of 1996 . India 2000 norms are at least 
Euro-I equivalent for all four-wheelers, Euro-II equivalent for noncommercial four-wheelers in the NCR (also referred to as Bharat Stage II), and are among the tightest norms in the world for two-wheelers.

It has been proposed by an inter ministerial task force committee to review the feasibility of Euro III emission norms for mega cities after 2005. A CPCB committee comprising representatives from refineries, research institutes like Indian Institute of Petroleum, ministries of Industry and Petroleum recommended a road map for the implementation of emission norms covering major cities and the whole country.

\section{Failure of the Executive and Intervention of the Judiciary}

\section{Implementation of Pollution Regulating Laws}

The nodal agency for implementing various legislations relating to environmental protection at the centre is the Ministry of Environment and Forests, and the Central Pollution Control Board (CPCB) established by it. At the state level, most states have set up Departments of Environment and State Pollution Control Boards (SPCBs).

The whole issue of pollution prevention and control is dealt with mainly by command and control methods. Voluntary regulations, fiscal instruments, and education and promotional measures are also being focused upon. In the command and control methods, the standards are determined and enforced by the central and state pollution control boards. The boards have implemented a pollution control programme whereby a total of 1551 large and medium units have been identified in the country under the 17 highly polluting industrial sectors. Such programmes need continuous monitoring until the target is attained. In order to encourage industries to manufacture their products in an environment friendly manner the CPCB has introduced an ECOMARK scheme to help the consumers to identify such products. As regards fiscal instruments, although the Tax Reform Committee in 1991 recommended excise taxes for dealing with externalities, the main focus 
of fiscal instruments has been to generate revenue rather than controlling pollution or conserving scarce resources.

Thus, despite the legislative and administrative efforts and fiscal incentives for pollution control, ambient standards of air and water pollution continue to be routinely exceeded and in some areas the quality has even deteriorated (Mehta, Mundle, and Sankar, 1996). This is attributable to the hiatus between the macro goals of our environmental policy and the micro nature of operational provisions for enforcement of the policy. Hence, though standards have been laid down for ambient air and water quality, actual enforcement relates mostly to some source emission standards laid down for individual polluters. Furthermore, the ambient and source standards are laid down independently, and unrelated in terms of the volume of polluting activities. Hence, it is quite conceivable that the quality of the environment may continue to deteriorate in spite of compliance by individual polluters. Additionally, the degree of compliance may also be poor.

\section{Determination of Standards}

The CPCB has stipulated baseline standards and the SPCBs can prescribe more stringent standards depending on the particular desires and requirements. There are three types of effluent standards for the purpose of discharge of effluents. These are concentration-based standards, equipment-based standards, and load or mass-based standards. The issue however, is not with the prescription of standards, but with their implementation. Often, an instance of dynamic instability in intergovernmental competition arises from laxity in implementing environmental standards.

Questions may be raised about the basis for setting standards and their relevance of the standard to surrounding ecosystem. According to Sankar (1999), determination of standards should be done on the basis of detailed cost benefit analysis. The standard setting in India does not give any chance to the polluters or the citizens to voice their opinion. The standards in India are set on the basis of industry studies undertaken by scientific and technical institutions appointed by the CPCB. These studies provide estimates of pollution emission and abatement cost subject to the various limitations that are inherent in such exercises. These standards are often replicated identically from those existing in different parts of the world without testing their relevance to 
the Indian situation. Another issue at the implementation level is whether a nation-wide uniform effluent standard is desirable. The carrying capacity and the trade-off between environmental quality and growth are determined and influenced by regional specificity. The standards, therefore, should vary with regions. However, fixing standards according to regional specificity may lead to the states lowering the standard to attract investment, eventually degenerating into a pollution haven. To prevent this tendency the Environment Protection Act, 1986 gives powers to the central and state governments to restrict or prohibit certain activities in ecologically fragile areas. The rules do not permit any state governments or SPCBs to lower the standards fixed by the central government in any region. The problem of implementation is, nevertheless, critical.

It may be pertinent to mention here that in 1988 the water act was amended to strengthen the implementation provisions. Now, the state boards can close a defaulting unit, the penalties are also raised and a citizen's initiative provision bolsters the enforcement machinery. In the industrialised state of Gujarat, a resolution was adopted in the legislature under Article 252 not to introduce the 1988 amendments thus continuing to allow the industries to pollute land and water-bodies. However, in 1995 this came to the notice of the Supreme Court when a writ petition was filed by a farmer against large-scale pollution of a canal called Kharicut. The court took a tough stand to implement the provisions of law and a cleaning operation which included closure, and fines. The construction of a pipeline to carry industrial waste water to effluent treatment plants was carried on for four year; these plans were implemented under the strict supervision of the High Court. This example clearly brings out that there is a big gap between the existence of law and its implementation. Similar instances have been reported from Tamil Nadu and Maharashtra (Shyam Divan and Armin Rosencranz, 2001). It may also be pointed out here that monitoring and enforcement through local level institutions will be much more effective in checking such pollution, the absence of delegation of power to such institutions forms the basis of executive failure and intervention by the judiciary.

\section{Enforcement of Standards}

In India poor enforcement of laws/rules occurs owing to unreliable information pertaining to quantities of effluents/emissions/solid 
wastes and their characteristics. There is information asymmetry since polluters know more about the sources, magnitudes, and concentration of pollutants as well as cost of controlling pollution than the regulators. It is very difficult for the regulating agencies to acquire and process information from thousands of units dispersed in their domain. The regulating agencies complain about "thin spread of institutions" for controlling pollution vis-a-vis the enormous spread of industrial units, thus making them very weak. ${ }^{12}$ The SPCBs suffer from acute resource constraints. They do not have adequate technical facilities and skilled personnel for monitoring the polluting units on even filing charges against them for violating standards. The amount of fines imposed is too less and is independent of the extent of violations. The courts take years to settle such cases owing to pendency of large number of other cases, causing the dispute settlement mechanism ineffective. Penalties such as imprisonment of officials, stoppage of water and electricity, and closure of units can impose hardships on the affected firms, but in a weak enforcement regime with the principal agent problem, collusion between regulators and the regulated units is common. As the cost of compliance upto the prescribed standards increases rapidly, with the extent of violation, non-compliance is a cheaper option than compliance for many polluters. Since dispute settlement by going to courts are time consuming and costly, it gives the regulating officers an opportunity to indulge in rent seeking activities. Besides, the state governments can intervene and influence the decisions of the SPCBs. Even though the SPCBs are supposed to be autonomous, they depend upon the state government for financial support and the members owe their positions to political patronage. Green rating, environmental audit, local community pressures etc. provide one mechanism for altering polluters' behaviour and bring pressure on government. This policy may work for large units, firms listed in stock markets or highly localised pollution. It is important that cost effectiveness of alternative options in framing of regulations, prescription of standards, and enforcement of rules should be accepted as a policy goal. The cost benefit analysis should be made mandatory in framing and enforcing environmental regulations.

\section{Intervention of Judiciary}

The inability to enforce environmental legislation has often led to affected parties, NGOs and the general public, taking recourse to legal action, mostly in the form of public interest litigations. This is aided by 
the fact that the courts have interpreted the fundamental right to life and personal liberty enshrined in Article 21 of the constitution to include the right to enjoy pollution free air and water.

Public Interest Litigation in India: Public Interest Litigation (PIL) in India is working on the planned rules evolved by the Supreme Court through the various decisions pronounced by it. The need for a PIL was felt by the Supreme Court when it reckoned the fact that large number of people in India are suffering silently in matters relating to their fundamental rights due to poverty, illiteracy and remoteness from the centre of power. The remedy available to citizens to go to the courts for the enforcement of the right to life under Article 21 and the growing environmental problems and consciousness has radically changed the situation in India. Some of the important PILs are mentioned below.

(i) Rural Litigation and Entitlement Kendra vs State of Uttar Pradesh ${ }^{13}$ : This case is said to be the harbinger of the new trend of PILs. The Supreme Court directed the closure of mining operation in the limestone quarries of Doon valley located in the foothills of the Himalayas when it found that it was creating ecological imbalance and was a health hazard to the local population. It held that although closure would cause hardship to the affected parties, it was necessary for protecting and safeguarding the rights of the people to live in a healthy environment and ensure ecological balance. It further directed that the affected areas be restored by afforestation and soil conservation programme to provide employment opportunities to the affected workers (Shyam Divan and Armin Rosencranz 2001).

(ii) M.C.Mehta vs Union of India ${ }^{14}$ : The Supreme Court directed the stopping of the working of tanneries discharging effluents in the Ganges river if they did not set up primary effluent treatment plants. It held that financial incapacity of the tanners to set up effluent treatment plants was irrelevant.

(iii) M.C.Mehta vs Union of India ${ }^{15}$ : The Supreme Court ordered the closing down of a chlorine plant of Shriram Industries after the oleum gas leak case. This case was decided by a five judge constitutional bench due to the gravity of the legal question under consideration. In this case the court ruled that there is absolute liability on hazardous industries. 
(iv) Indian Council for Envirolegal action vs Union of India ${ }^{16}$ : In this case the Supreme Court ordered remedial action and compensation to the people affected by lethal waste left for years after chemical industries were closed. The compensation was in line with absolute liability principle.

(v) In its order on a PIL related to dumping of hazardous and noxious material by industrial units throughout India filed by Research Foundation for Science, a NGO, the Supreme Court issued a direction to the Union ministry for environment and forests to take the necessary steps within a specified time frame. The Supreme Court warned the ministry that if the top officers concerned did not measure upto their duties and enforce the provisions of the Environment Protection Act of 1986, the court would be constrained to record a "judicial finding of failure to perform their duties against them". The court also threatened that the judicial finding will be recorded in their service records.

Some other important decisions of the supreme court are: (i) closure of 69 foundries in Howrah, in West Bengal state for their failure to install pollution control devices in 1996; (ii) closure of 39,000 illegal industrial units operating in residential areas in Delhi and shifting 513 of them to locations outside the city for causing health damage to citizens; (iii) closing of aquaculture farms within 500 metres of the sea coast in 1997; (iv) shifting 550 tanneries located in East Calcutta in 1997 and setting up of a environmental pollution fund with each unit paying Rs. 10,000 as fine to be used for cleaning up the river Hoogly on the banks of which the tanneries were located; and $(\mathrm{v})$ ban on felling of trees and ruling that the running of saw mills of any kind, including veneer and plywood mills was prima facie, a violation of the provisions of the Forest Conservation Act of 1980.

As PIL cases began crowding the court docket, often in the form of skimpy petitions based on newspaper reports, several problems are cropping up in relation to securing detailed facts, receiving experts opinion on complex social and scientific issues, and ensuring continuous supervision of judicial orders. Sometimes the official machinery is unreliable, slow and biased, and unable to provide impartial assessment of facts. On such occasions the court can appoint special commissions to gather facts and data. With regard to complex scientific issues, the Supreme Court most often relies on the National Environment Engineering Research Institute (NEERI), Nagpur. Sometimes to ease the 
burden of evidence, the court may resort to a judicial notice of "facts". For example in a petition seeking to reduce pollution in river Ganges, the Supreme Court dispensed with the need for hard scientific fact on the health effects of pollution and the damage it caused to riparian property. The Supreme Court went through certain books and writings and simply assumed that such injuries had occurred or were likely to occur and proceeded to issue remedial action.

Frequently, environmental cases need independent scientific expertise for decision making. On such occasions the judges appoint a committee of experts to probe scientific questions and advise the court on the course of action. Like special commissions, the expert committees are appointed under the inherent powers of the courts under Article 32 and 226 of the constitution. The court treats the opinion of such committees with great reverence since they are eminent scientists drawn from leading institutions. ${ }^{17}$

The flip side of PIL is that it may be construed as ingress into fields traditionally reserved for the executive. An example may be the Dehradun Quarrying Case where the Supreme Court resolved the development policy which included conserving nature, preserving jobs and protecting substantial business investments while deciding to close a number of limestone quarries in the Mussoorie Hills and allow others to operate under detailed conditions. The problem relates to the competence of the court to review highly technical reports of various experts when they differ in their diagnosis and conclusions.

Enforcement of environmental law through the courts has advantages as well as pitfalls. The judge who presided over the Ganges pollution case had to persistently cajole and drive recalcitrant industries and public authorities in the Ganges basin to comply with pollution norms. The polluting units included hundreds of large polluting industries in the states of Uttar Pradesh, Bihar, and West Bengal, municipal corporations, the Eastern Railways, giant thermal power plants, numerous small industries, and tanneries. The first task of the court was to identify the polluters for which it turned to the lawyer who filed the PIL. Once identified, all units were issued orders to meet effluent standards within three months or else face closure. To emphasise the urgency, the orders threatening closure were issued without giving due hearing to the companies. The court directed the state pollution control boards to serve the notice without any loss of time. The units had to report to the boards. 
When the units reached the prescribed discharge levels the boards were directed by the court to inspect the working of the emission treatment plants. The court was clearly unhappy with the performance of the pollution control boards and regretted that the SPCBs could not perform even an elementary function. The widespread impression was that court orders were misused by the dishonest board officials to seek rent. The court finally entrusted the National Environmental Engineering Institute to perform the job. ${ }^{18}$

Public interest litigation and judicial activism has been extremely effective in India in dealing with the problems of executive failure, which have been so rampant in matters of environmental concerns. In many senses the courts provide a remedy to massive bureaucratisation and a very non-transparent, nebulous, ineffective and corrupt administrative structure of state and central governments. Environmental conservation in India without the interference of the courts would have been in a state of a shambles. The judicial activism has been an effective remedy for administrative and executive failures. It has brought about a sense of accountability and responsibility in the otherwise lax bureaucracy. This has been an important part of "checks and balances" in Indian federalism.

While the judicial intervention has been an effective check against executive failure, excessive intervention could result in taking over the functions of the executive by the courts and in such cases, there is no remedy for the wrong decisions. The Supreme Court's attempt to solve the environmental regulation through judicial pronouncements is certainly praiseworthy, but it basically highlights the failure of the executive to enforce environmental laws and regulations. The reluctance of the executive in environmental regulation is not due to the assignment system itself, nor can it be attributed to unstable intergovernmental competition, but seems to arise from asymmetric information and structure of incentives leading to rent seeking behaviour of the regulators. Judicial activism cannot be a satisfactory solution to executive failure for, judicial intervention can at best be ad hoc solutions and by itself, it does not help to evolve a rule-based system of environmental governance.

One problem with the judicial decisions is that the court approaches the problem purely from the angle of 'right'. Some of its decisions relating to water pollution are not implementable. In AIR 1980 
SC 1622 (Ratlam vs. Vardhichand), the court held that the budget constraints did not absolve a municipality from providing sanitation facilities. It compelled the municipality to implement a sanitation scheme. Most of the local bodies do not have the resources to set up and operate sewerage systems or provide water treatment. Even in executive decisions relating to the prescription of standards, the costs of implementation, or the existence of cost-effective technologies etc. are not considered.

Besides, while the Supreme Court has shown keenness to deal with environmental issues, the lower courts have been extremely reluctant to take up environmental cases. There is also a serious problem of corruption in lower courts, which may not yield satisfactory solutions. ${ }^{19}$ Another serious problem with environmental protection laws in India is that they come under criminal laws and not civil laws. This is the reason the laws and the court consider violation or no violation and not the extent of violation. Thus, in the Indian context, more than the assignment of environmental function between different levels of government, the problems have centred around implementation and the overlapping roles of executive and judiciary.

\section{Concluding Remarks}

This paper deals with the assignment system and implementation mechanism relating to the environmental functions in India. It analyses the effectiveness of environmental governance in the country by examining forest, water, and air. It analyses the system of assignments, problems arising from the overlapping assignments, bargaining, and dispute resolution mechanisms in regard to the three elements. It also analyses the implementation aspects of environmental policy to examine the effectiveness of policies and institutions relating to environmental governance.

The assignment of environmental power in Indian federalism is reasonably clear. Broadly, while the central government has the responsibility of determining the overall policy frame, the subnational governments are involved in implementation. Thus, the assignment 
system attempts to minimise transaction costs by providing sufficient scope for decentralised governance of environmental functions. At the same time, the central government has overriding powers to avoid unstable competition and institute mechanisms to resolve inter-state disputes.

In implementing environmental regulations, particularly with regard to the protection of forests and management of water systems, decentralised solutions involving participatory approaches have shown promise. The institutions of JFM and village forest committees have enhanced the stake of the local population in the development of forestry. Similarly, the water users' associations have helped in improved maintenance of irrigation canals. Instances of successful decentralised approach can also be found in rainwater harvesting and watershed development. However, decentralised solutions may also lead to elite capture unless adequate safeguards are taken.

The implementation of environmental functions has been a major concern. In most cases, a critical factor impeding effective implementation is the structure of incentives to bureaucracy and policy makers and influence of polluters on them. Besides, the environmental regulators do not have access to modern technology to measure and regulate pollution levels, and the resources in their possession are inadequate.

Although the assignment of environmental functions to different levels of government seems to be satisfactory, there is considerable overlap between the roles of executive and judiciary in the enforcement of environmental regulation. Often, we see the executive failure in environmental regulation leading to the intervention by the Supreme Court. Interpreting that access to clean water and air as a fundamental right, the courts have pronounced several judgements on the implementation of environmental regulation, often, taking over the role of the executive. This has helped to resolve issues in the short term and in some cases has led to improvement in environmental quality, it is important to avoid ad hoc and arbitrary solutions. There is also the problem of capacity of the Supreme Court to take into account changes in technology. In other words, replacement of executive action through judicial activism cannot be a satisfactory solution to environmental regulation. This calls for reform of the incentive structure and institutions 
of governance to make the executive much more sensitive and accountable to environmental issues.

The paper has also analysed the issues of inter-state river water disputes. The conclusion of the paper is that effective resolution mechanism for Inter-state river water dispute simply does not exist. The ruling governments at the centre have simply used the disputes for their short-term political gains. Neither the tribunals, nor the Supreme Court order has ensured compliance by the parties to the dispute nor do they have the potential to provide effective solution to the problem. The river water dispute has become highly emotive and threatens the very federal fabric of the country. 


\section{References}

Alavi, H and J. Harris (eds.), 1989. Sociology of Developing Societies. Macmillan, London: South Asia.

Bardhan, P. 1984. The Political Economy of Development in India. New Delhi: Oxford University Press.

Bhaskar, Vira 1995. "Institutional Change in India's Forest Sector, 1976 - 1994: Reflections on State Policy", OCEES Research Paper No.5, URL: www.mansfield.ox.ac.uk/ocees/pages/people/vira.htm

Brandon, Carter and Kirsten Hommann, 1995. The Cost of Inaction: Valuing the Economy-wide Cost of Environmental Degradation in India. Asia Environment Division, The World Bank, Washington D.C.

Breton, Albert 1995. Competitive Governments: An Economic Theory of Politics and Public Finance. Cambridge: Cambridge University Press.

2002. "An Introduction to Decentralisation Failure" in Ehtisham Ahmad and Vito Tanzi (eds.), Managing Fiscal Decentralisation. London: Routledge.

Brewer, Jeffrey D. and Shashi Kolavalli, 1998. "Assessing Common Property Institutions", Presented at Crossing Boundaries, the seventh annual conference of the International Association for the Study of Common Property, Vancouver, British Columbia, Canada: June 10-14, 1998.

Coase, R. 1960. The Problem of Social Cost, Journal of Law and Economics, Vol. 1: 1-44

Divan Shyam, and Armin Rosencranz, 2001. Environmental Law and Policy in India. New Delhi: Oxford University Press.

Gadgil, M. and R. Guha, 1992. This Fissured Land: An Ecological History of India. Delhi: Oxford University Press. 
Geijer, J.C.M.A, 1996. "Irrigation Management Transfer in Asia", URL: http:// www.waterinfo.net, March 10, 2004.

Government of India (Gol), 1987. National Water Policy. New Delhi: Ministry of Water Resources.

Environment and Forest.

1990. National Forest Policy. New Delhi: Ministry of 1992, National Perspectives for Water Resources Development. New Delhi: National Water Development Agency.

1993. Re-assessment of Water Resources Potential of India. New Delhi: Central Water Commission.

, 1997. Report of the Working Group on Participatory Irrigation Management for the Ninth Plan. New Delhi: Ministry of Water Resources.

, 1999. Report of the Working Group on Perspectives of Water Requirements, National Commission for Integrated Water Resources Development. New Delhi: Ministry of Water Resources.

Water Resources.

2002. National Water Policy. New Delhi: Ministry of

Guha, Ramachandra 1983. "Forestry in British and Post - British India: A Historical Analysis" Economic and Political Weekly, Vol. XVIII (44): $1882-96$.

Gupta, Shreekant 1996. "Environmental Policy and Federalism in India". National Institute of Public Finance and Policy, New Delhi (mimeo).

Delhi: Centre for Policy Research.

1999. Conflict Resolution: Three River Treaties. New

lyer, Ramaswamy R. 2003. Water Perspectives, Issues, Concerns. New Delhi: Sage Publications.

Mehta, S. Sudpito Mundle, and U. Sankar, 1996. Controlling Pollution Incentives and Regulation. New Delhi: Sage Publications. 
Moench, M 1997. "National Importance of Groundwater and Power Supply Management with particular reference to Electricity Pricing and Supply", paper presented at the workshop on Groundwater Regulation and Management, Feb, 17-19. New Delhi.

Musgrave, R. A. 1983. "Who Should Tax, When and What?" in Charles McLure, Jr. (ed.), Tax Assignment in Federal Countries. Canberra; The Australian National University Press.

Nadkarni, M.V. 1989. The Political Economy of Forest Use and Management. New Delhi: Sage Publications.

Oates, Wallace E, 1999. "An Essay on Fiscal Federalism", Journal of Economic Literature, Vol 37(3):1120 - 1149

Ramana, M.V.V. 1992. Inter-State River Water Disputes in India, Madras: Orient Longman.

Rao, Govinda M. and N. Singh, 2004. The Political Economy of Federalism in India. New Delhi: Oxford University Press.

Richards, A. and N. Singh, 1996. "Water and Federalism: India's Institutions Governing Inter-State River Waters", University of California (Santa Cruz), Working Paper URL: econ.ucsc.edu/ boxjenk/ waterdom.pdf

Sankar, U. 1999. "Laws and Institutions Relating to Environmental Protection in India", Madras School of Economics, Chennai. Occasional Paper No. 2.

Sankar. U. 2002. "Design and Enforcement of Fiscal Instruments for Pollution Control in India", in Rao, Govinda M. (ed.) Development, Poverty, and Fiscal Policy. New Delhi: Oxford University Press.

Sharma, S. 2003. "Redefining Water Governance", URL: http://pikespeak.uccs.edu/

Singh, N 1997. "Issues in Local Government Reforms in India", University of California (Santa Cruz), Working Paper URL: econ.ucsc.edu/ boxjenk/locgov5.pdf 
Vermillion, Douglas 1991. "Water User's Association”, Working Paper, International Food Policy Research Institute.

Wade, R 1988. Village Republics: Economic Condition for Collective Action in South India. Cambridge: Cambridge University Press.

World Bank, 1991. India: Irrigation Sector Review. Washington D. C.

World Bank, 1998. India-Water Resource Management Review. Washington D. C. 


\section{Endnotes}

${ }^{1}$ The province of Alberta in Canada, for example, gets much of its revenues from
oil resources and does not impose the retail sales tax on its citizens.
2 The words "union" and "centre" are used interchangeably in this paper.
3 There are also other acts with implications on environmental regulations.
These include, Factories Act, 1948 which mandates the treatment of liquid
effluents, gases and fumes generated during production process before disposal
and the Insecticides Act of 1968, which regulates all aspects of use of pesticides
including the monitoring of insecticides residue in the environment. There are
also other acts related to the environment such as, The Prevention of Food
Adulteration Act of 1954, The River Boards Act of 1956, The Mines and Minerals
(Regulation and Development) Act of 1957, The Ancient Monuments and
Archaeological Sites and Remains Act of 1958, and The Atomic Energy Act of
1962 . ${ }^{4}$ It may be noted that the PIL on air pollution pertained to local issues though filed in the national court.

${ }^{5}$ This section has been compiled on the basis of information available at the website of Ministry of Environment Forest, URL: www.envfor.nic.in/, Water Resources Ministry URL: wrmin.nic.in/, and Sustainable Development Network Programming of National Informatics Center URL: www.sdnp.delhi.nic.in/, and The Energy and Resource Institute URL: www,teriin.org.

${ }^{6}$ The programmes implemented by the Ministry of Agricultural and Co-operation are National Watershed Development Projects for Rainfed Areas, watershed Development Projects in Shifting Cultivation Areas, Integrated Watershed Development Projects, The Karnataka and Madhya Pradesh Watershed Development Projects, and the watershed projects at Tirunelveli, Ramnathapuram and Koraput.

7 The programmes under the Ministry are Desert Development Programme, Drought Prone Area Programme, Integrated Watershed Development Programme which carries out water resources development activities including checking dams and water harvesting structures.

${ }^{8}$ A.J.James (2003) Institutional Challenges for Water Resource Management: India and South Africa WHIRL Project Working Paper 7 URL: www.nri.org/WSSIWRM/reports.htm

${ }^{9}$ Ministry of Rural Development, and Ministry of Environment and Forest of the Central Government, Ministry of Panchayati Raj and Rural Development, Irrigation Departments of State Governments.

${ }^{10}$ We shall come back to the issue of water pollution with respect to its regulation, enforcement of standards and institutions in the subsequent sections. We discuss issues related to air pollution in the next section so that the common institutions which enforce pollution related regulations can be analysed with respect to both air and water pollution. 
${ }^{11}$ Brandon, Carter and Kristen Hommann, 1995 The Cost of Inaction: Valuing the Economy-wide Cost of Environmental Degradation in India, Asia Environment Division, The World Bank, Washington, D.C.

${ }^{12}$ The total strength of employees of Pollution Control Board in India is 600 as compared to 17000 in USEPA

${ }^{13}$ A.I.R. 1985 SC 652

${ }^{14}$ A.I.R. 1987 SC 965,1086 and 1988 S.C. 1037 and 1135

${ }^{15}$ A.I.R. 1987 SC 1086

${ }^{16}$ A.I.R.1996 SC 1037

${ }^{17}$ The Supreme Court accepted the Shekhar Singh Committee recommendations which was appointed by it to look into matters related to saving the fragile ecosystem of the Andaman and Nicobar Islands in spite of heavy opposition from a number of quarters.

${ }_{18}$ Compiled from newspaper reports of Times of India and The Hindu

19 The Chief Justice lamented in public of his inability to prevent rampant corruption in the lower courts due to lack of effective power. See, Times of India, February 13, 2004. 